\title{
Hubungan antara tingkat kemandirian dan kebugaran dengan kualitas hidup lansia
}

\author{
Berka Phillia Ningrum ${ }^{1}$, Fransisca Chondro $^{2}$
}

\begin{abstract}
ABSTRAK
\section{LATAR BELAKANG}

Data kependudukan Indonesia menunjukkan peningkatkan populasi lansia setiap tahunnya. Kondisi ini berdampak pada peningkatkan prevalensi penyakit degeneratif pada lansia yang kemudian berdampak pada tingkat kemandirian dan kebugaran lansia. Penelitian yang sudah dilakukan masih menunjukkan kontroversi kedua kondisi tersebut di atas dengan kualitas hidup lansia.

\section{METODE}

Penelitian ini merupakan peneliitan potong silang yang dilakukan pada 86 lansia di RW 01 Jelambar Baru, Jakarta Barat. Data dikumpulkan dengan cara wawancara menggunakan kuesioner Barthel Index untuk mengukur tingkat kemandirian, Non exercise fitness test untuk mengukur tingkat kebugaran dan WHOQOL-BREF untuk mengukur tingkat kualitas hidup responden. Analisa bivariat dilakukan untuk mengetahui hubungan tingkat kemandirian dan kebugaran dengan kualitas hidup lansia, menggunakan uji statistik Fisher's Exact Test dan Chi Square dengan tingkat kemaknaan yang digunakan besarnya 0.05 .
\end{abstract}

\section{HASIL}

Analisis hubungan tingkat kemandirian dengan kualitas hidup lansia menggunakan Fisher's Exact Test, di dapatkan hasil $\mathrm{p}=0.235$. Analisis hubungan tingkat kebugaran dengan kualitas hidup lansia menggunakan uji Chi-Square didapatkan hasil $\mathrm{p}=0.708$.

\section{KESIMPULAN}

Tidak terdapat hubungan antara tingkat kemandirian dan kebugaran dengan kualitas hidup lansia.

\author{
${ }^{1}$ Program Studi Kedokteran, \\ Fakultas Kedokteran Universitas \\ Trisakti, Indonesia \\ 2 Departemen Ilmu Faal, Fakultas \\ Kedokteran Universitas Trisakti, \\ Indonesia
}

\section{Korespondensi:}

Fransisca Chondro

Departemen Ilmu Faal, Fakultas

Kedokteran Universitas Trisakti,

Indonesia, Jalan Kyai Tapa No. 260, Grogol, Jakarta Barat

Email:

fransisca_chondro@trisakti.ac.id

J Biomedika Kesehat 2019;2(4):138-

143

DOI: 10.18051/JBiomedKes.2019.

v2.138-143

pISSN: 2621-539X / eISSN: 2621-5470

Artikel akses terbuka (open access) ini didistribusikan di bawah lisensi Creative Commons Attribution 4.0 International (CC-BY 4.0)

Kata kunci: kemandirian, kebugaran, kualitas hidup, lansia 


\section{ABSTRACT}

\section{Correlations between independence level and fitness with quality of life in the elderly}

\section{BACKGROUND}

Indonesian population data show that there is an increase in the population of elderly each year. This condition has an impact in the increasing prevalence of the degenerative disease in elderly, that also has an impact in the level of independence and fitness in the elderly. Until now, there are still controversies regarding the relationship between the level of independence and fitness with the quality of life on the elderly.

\section{METHODS}

A cross-sectional study was conducted using observational approach and a total of 86 elderly in RW 01 Jelambar Baru, West Jakarta were included. Data was collected by interviewing the respondence regarding the independence using Barthel Index, the fitness level using non excercise fitness test, and the quality of life using WHOQOLBREF. Fisher's Exact dan Chi Square test were done to data analysis with $\mathrm{p} \leq 0.05$.

\section{RESULT}

The result shown that independence level have associations with quality of life $(p=0.235)$, while not association with quality of life $(\mathrm{p}=0.708)$.

\section{CONCLUSION}

There is no correlations between independence level and fitness with quality of life.

Keywords: level of independence, fitness, quality of life, elderly

\section{PENDAHULUAN}

Dalam waktu hampir lima dekade ini, persentase lansia di Indonesia meningkat sekitar dua kali lipat, yaitu menjadi $8.97 \%$ ( \pm 23 juta). Hasil Susenas 2017 menunjukkan terdapat lima provinsi dengan persentase lansia lebih dari $10 \%$, yaitu : DI Yogyakarta (13.90\%), Jawa Tengah (12.46\%), Jawa Timur (12.16\%), Bali (10.79\%) dan Sulawesi Barat (10.37\%). ${ }^{(1)-}$

Semakin bertambahnya usia maka terjadi kemunduran fisik, psikis, dan sosial pada lansia yang dapat digambarkan melalui empat tahap yaitu kelemahan, keterbatasan fungsional, ketidakmampuan dan keterhambatan yang akan dialami bersamaan dengan proses kemunduran akibat proses menua. ${ }^{(2)}$ Proses penurunan fungsi fisiologis dapat menimbulkan penyakit tidak menular yang banyak muncul pada lansia. Selain itu, penyakit degeneratif dapat menurunkan daya tahan tubuh sehingga lansia rentan terkena infeksi penyakit menular. Pada lansia juga terjadi penurunan masa dan kekuatan otot, laju denyut jantung maksimal, toleransi latihan, kapasitas aerobik dan terjadinya peningkatan lemak tubuh. (3).

Menurut WHO, untuk menilai kualitas hidup terdapat aspek kesehatan fisik, kesehatan psikologis, hubungan sosial, dan hubungan dengan lingkungan mereka. Pada kesehatan fisik, dapat ditentukan diantaranya melalui kemandirian dalam melakukan ADLs (Activity of Daily Living), tingkat energi dan kelelahan, mobilitas, rasa nyeri, tidur dan istirahat. ${ }^{(4)}$ Kemandirian dalam melakukan ADLs adalah suatu keadaan dimana lansia mampu untuk mengurus atau mengatasi kepentingannya sendiri tanpa memerlukan bantuan orang lain. ${ }^{(5)}$ Kemandirian pada lansia sangat penting untuk merawat dirinya sendiri dalam memenuhi kebutuhan dasar manusia. ${ }^{(6)}$

Penelitian terdahulu menyatakan terdapat hubungan antara kemandirian dengan kualitas hidup lansia. ${ }^{(7)}$ Penelitian lain terhadap populasi lansia di Kamboja juga memperlihatkan hubungan antara ketergantungan yang medium dalam ADLs dengan kualitas hidup yang rendah. ${ }^{(8)}$ Hasil yang berbeda menunjukkan tidak terdapat hubungan antara tingkat kemandirian dengan kualitas hidup lansia. ${ }^{(9)}$

Selain tingkat kemandirian, hal yang dapat mempengaruhi kualitas hidup lansia adalah kemampuan dalam melakukan aktivitas fisik. Kemampuan dalam melakukan aktivitas fisik dapat dinilai pada kebugaran seseorang. Seseorang dikatakan bugar jika ia sehat dan mampu melakukan kegiatan sehari-hari dengan baik tanpa mengalami kelelahan yang berarti dan masih memiliki semangat untuk menikmati waktu santai atau kegiatan lain. ${ }^{(10)}$ Kebugaran daya tahan jantung dan paru didefinisikan sebagai kapasitas maksimal untuk menghirup oksigen atau dapat disebut $\mathrm{VO}_{2}$ max. Semakin tinggi $\mathrm{VO}_{2}$ max maka ketahanan tubuh saat berolahraga juga semakin 
tinggi, berarti seseorang yang memiliki tingkat $\mathrm{VO}_{2}$ max tinggi tidak akan cepat mengalami kelelahan setelah melakukan berbagai aktivitas. (11) Penelitian terhadap lansia di Puskesmas Wonokromo,Surabaya memperlihatkan hubungan antara faktor kebiasaan olahraga dengan kualitas hidup lansia penderita DM tipe $2 .{ }^{(12)}$ Hasil berbeda memperlihatkan tidak ada korelasi antara kualitas hidup dengan kebugaran fisik. ${ }^{(13)}$ Dengan adanya ketergantungan dalam melakukan aktivitas seharihari karena menurunnya fungsi pada lansia dan rendahnya kebiasaan dalam berolahraga sehingga tubuh tidak bugar akan menghambat lansia dalam menjalankan kehidupan sehari-hari dan mengakibatkan rendahnya kualitas hidup lansia.

Berdasarkan penjelasan di atas, terlihat adanya peningkatkan jumlah lansia serta masih adanya kontroversi mengenai hubungan antara kemandirian dan kebugaran dengan kualitas hidup lansia, serta meningkatnya jumlah penduduk lansia di Indonesia maka dari itu peneliti tertarik untuk mengambil judul penelitian ini untuk diteliti.

\section{METODE}

Penelitian ini menggunakan studi observasional analitik dengan desain cross sectional dan dilakukan di wilayah RW01 Jelambar Baru, Grogol, Jakarta Barat. Pemilihan sampel diambil dengan cara consecutive non random sampling, dimana subyek yang dijumpai dan memenuhi syarat penelitian dijadikan sampel sampai jumlah yang dibutuhkan. Kriteria inklusi pada penelitian ini adalah lansia pria dan wanita berusia $\geq 60$ tahun, bersedia menjadi responden dan mampu berkomunikasi dengan baik, sedangkan kriteria eksklusinya adalah lansia yang tidak dapat berdiri. Jumlah subjek penelitian yang didapatkan pada penelitian ini adalah 86 orang lansia.

Data dikumpulkan dengan cara wawancara menggunakan kuesioner Barthel Index untuk menilai tingkat kemandirian, non exercise fitness test untuk menilai tingkat kebugaran dan WHOQOL-BREF untuk menilai kualitas hidup lansia. Analisa univariat mendeskripsikan karakteristik responden, kualitas hidup lansia, kebugaran dan tingkat kemandirian. Analisa bivariat dilakukan untuk mengetahui hubungan tingkat kemandirian dan kebugaran dengan kualitas hidup lansia, menggunakan uji statistik Fisher's Exact Test dan Chi Square dengan tingkat kemaknaan yang digunakan besarnya 0.05 .

\section{HASIL}

Berdasarkan Tabel 1, penelitian ini sebagian besar di dominasi oleh wanita yaitu sebesar $62.8 \%$ dan usia lansia yang termasuk golongan elderly (60-74 tahun) yaitu sebesar $88.4 \%$. Pada penelitian ini, hampir sebagian besar lansia mempunyai tingkat kemandirian dalam menjalankan aktivitas sehari-hari yang mandiri yaitu sebanyak $90.7 \%$ dan tingkat kebugaran yang sedang yaitu $46.5 \%$. Dari aspek kualitas hidup terlihat bahwa hanya aspek lingkungan baik yang dimiliki oleh sebagian besar lansia. Lebih dari separuh lansia memiliki aspek kesehatan fisik, psikologis, dan sosial yang kurang baik. Secara keseluruhan, lansia yang memiliki kualitas hidup yang baik yaitu sebanyak $55.8 \%$.

Tabel 1. Karakteristik demografi, tingkat kemandirian, kebugaran dan kualitas hidup lansia

\begin{tabular}{|c|c|c|}
\hline Karakteristik & n & $\%$ \\
\hline $\begin{array}{l}\text { Jenis kelamin } \\
\text { Laki-laki } \\
\text { Perempuan }\end{array}$ & $\begin{array}{l}32 \\
54\end{array}$ & $\begin{array}{l}37.2 \\
62.8\end{array}$ \\
\hline $\begin{array}{l}\text { Usia } \\
\quad \text { Elderly } \\
\quad \text { Old }\end{array}$ & $\begin{array}{l}76 \\
10\end{array}$ & $\begin{array}{l}88.4 \\
11.6\end{array}$ \\
\hline $\begin{array}{l}\text { Kemandirian } \\
\text { Mandiri } \\
\text { Tergantung }\end{array}$ & $\begin{array}{c}78 \\
8\end{array}$ & $\begin{array}{c}90.7 \\
9.3\end{array}$ \\
\hline $\begin{array}{l}\text { Kebugaran } \\
\text { Baik } \\
\text { Cukup baik } \\
\text { Sedang } \\
\text { Buruk }\end{array}$ & $\begin{array}{c}4 \\
26 \\
40 \\
16\end{array}$ & $\begin{array}{l}4.7 \\
30.2 \\
46.5 \\
18.6\end{array}$ \\
\hline $\begin{array}{l}\text { Aspek kualitas hi } \\
\text { Fisik } \\
\text { Baik } \\
\text { Kurang baik }\end{array}$ & $\begin{array}{l}27 \\
59\end{array}$ & $\begin{array}{l}31.4 \\
68.6\end{array}$ \\
\hline $\begin{array}{l}\text { Psikologis } \\
\text { Baik } \\
\text { Kurang baik }\end{array}$ & $\begin{array}{l}42 \\
44\end{array}$ & $\begin{array}{l}48.8 \\
51.2\end{array}$ \\
\hline $\begin{array}{l}\text { Sosial } \\
\text { Baik } \\
\text { Kurang baik }\end{array}$ & $\begin{array}{l}33 \\
53\end{array}$ & $\begin{array}{l}38.4 \\
61.6\end{array}$ \\
\hline $\begin{array}{l}\text { Lingkungan } \\
\text { Baik } \\
\text { Kurang baik }\end{array}$ & $\begin{array}{l}70 \\
16\end{array}$ & $\begin{array}{l}81,4 \\
18.6\end{array}$ \\
\hline $\begin{array}{l}\text { Kualitas hidup } \\
\text { Baik } \\
\text { Kurang baik }\end{array}$ & $\begin{array}{l}48 \\
38\end{array}$ & $\begin{array}{l}55.8 \\
44.2\end{array}$ \\
\hline
\end{tabular}

Dari Tabel 2 didapatkan bahwa pada kelompok lansia yang memiliki ketergantungan (tidak mandiri), didapatkan 5 dari 8 lansia memiliki kebugaran yang kurang baik. Hal yang 
Tabel 2. Hubungan tingkat kemandirian dan kebugaran dengan kualitas hidup lansia

\begin{tabular}{|c|c|c|c|}
\hline \multirow[b]{2}{*}{ Variabel } & \multicolumn{2}{|c|}{ Kualitas hidup } & \multirow[b]{2}{*}{$\mathbf{p}$} \\
\hline & $\begin{array}{c}\text { Baik } \\
\text { (n) }\end{array}$ & $\begin{array}{c}\text { Kurang baik } \\
\text { (n) }\end{array}$ & \\
\hline \multicolumn{4}{|l|}{ Kemandirian } \\
\hline Mandiri & 45 & 33 & $0.235^{*}$ \\
\hline Tergantung & 3 & 5 & \\
\hline \multicolumn{4}{|l|}{ Kebugaran } \\
\hline Baik & 2 & 2 & $0.708 * *$ \\
\hline Cukup baik & 16 & 10 & \\
\hline Sedang & 23 & 17 & \\
\hline Buruk & 7 & 9 & \\
\hline Baik & 2 & 2 & \\
\hline
\end{tabular}

sama juga terlihat dari hubungan antara kebugaran dan kualitas hidup. Dari 16 lansia yang memiliki kebugaran yang buruk, 9 diantaranya memiliki kualitas hidup yang kurang baik. Namun hasil uji statistik mengenai hubungan keduanya didapatkan nilai $\mathrm{p}>0.05$ dan mengindikasikan bahwa tidak terdapat hubungan bermakna antara kedua variabel tersebut.

Uji Chi-Square telah dilakukan untuk mengetahui hubungan tingkat kebugaran dengan kualitas hidup lansia, dan didapatkan hasil $\mathrm{p}=0.708$ yang dimana bila nilai $\mathrm{p}>0.05$ artinya tidak terdapat hubungan yang bermakna secara statistik antara kedua variabel tersebut. Dari tabel diatas dapat disimpulkan lansia yang memiliki tingkat kebugaran cukup baik dan sedang cenderung memiliki kualitas hidup lebih baik, dan yang memiliki kebugaran yang buruk cenderung memiliki kualitas hidup yang kurang baik.

\section{PEMBAHASAN}

Berdasarkan hasil uji statistik pada penelitian ini, tidak terdapat hubungan antara tingkat kemandirian dengan kualitas hidup lansia dengan hasil $\mathrm{p}=0.235(\mathrm{p}=<0.05)$. Hasil penelitian ini sejalan dengan penelitian yang menunjukkan tidak terdapat hubungan antara tingkat kemandirian dengan kualitas hidup lansia. Tidak adanya hubungan antara tingkat kemandirian dengan kualitas hidup lansia kemungkinan disebabkan karena terdapat faktor-faktor lain yang mempengaruhi kualitas hidup lansia. ${ }^{(9)}$ Menurut WHO, kualitas hidup seorang lansia dipengaruhi oleh empat aspek yaitu aspek fisik, psikologis, sosial dan lingkungan. Kemandirian dalam melakukan ADLs merupakan salah satu bagian dalam aspek fisik kualitas hidup lansia. ${ }^{(4)}$

Pada penelitian ini, didapatkan kualitas hidup lansia dari aspek fisik, psikologis, sosial dalam kategori yang kurang, tetapi dari aspek lingkungan lansia di RW 01 Jelambar Baru, Grogol, Jakarta Barat memiliki lingkungan yang baik. Hal ini dapat mempengaruhi kualitas hidup lansia, karena lansia belum bisa memperoleh nilai maksimal di keempat faktor yang mempengaruhi kualitas hidup menurut WHOQOL-BREF, maka dari itu diperlukan upaya peningkatan kualitas hidup dari kurang baik menjadi baik secara menyeluruh pada keempat aspek yang mempengaruhi kualitas hidup untuk mencapai kehidupan lanjut usia yang sejahtera. ${ }^{(14)}$

Hasil yang didapatkan pada penelitian ini tidak sejalan dengan penelitian yang menyatakan terdapat hubungan kualitas hidup dengan ADLs pada lansia. Hal ini dapat disebabkan oleh adanya beberapa perbedaan antara lain jumlah sampel yang berbeda di mana jumlah tersebut lebih besar dari penelitian ini. Selain itu, penelitian Long dkk juga menggunakan instrumen yang berbeda yaitu instrumen indeks Katz untuk menilai kemandirian dan WHOQOL-OLD untuk menilai kualitas hidup lansia. Indeks Katz digunakan terutama untuk menilai kemandirian dalam aktivitas sehari-hari meliputi 6 aktivitas sedangkan Indeks Barthel meliputi 10 aktivitas. ${ }^{(8)}$

Penelitian lain mengatakan semakin baik dukungan keluarga yang dimiliki dan kemampuan ADLs seorang lansia, maka semakin baik juga 
kualitas hidupnya. Menurunnya kualitas hidup dapat terjadi karena adanya gangguan fungsional, disabilitas, dan cedera. Adanya penyakit pada sistem fungsi tubuh yang terjadi karena usia dapat menyebabkan lansia menjadi semakin tergantung dalam menjalankan ADLs dan aktivitas sosial, sehingga dapat memperburuk kualitas hidupnya. (15)

Penelitian juga menyatakan terdapat hubungan antara kemandirian dengan kualitas hidup lansia. Hal ini dapat disebabkan oleh adanya perbedaan dominasi usia responden. Pada penelitian yang dilakukan di desa Margajaya kecamatan Ngamprah dengan jumlah sampel 72 lansia ini, usia lansia sebanyak $56.1 \%$ berada di kelompok 75-90 tahun, dimana hal ini berbeda dengan penelitian ini yang sebagian besar berada di kelompok usia 60-74 tahun. Instrumen yang digunakan untuk menilai kemandirian juga berbeda, yaitu menggunakan kuesioner berisi 21 pertanyaan. Hasil penelitianya didapatkan lansia yang mandiri dalam melakukan ADLs mempunyai kualitas hidup yang lebih baik dibandingkan yang tidak mandiri. ${ }^{(7)}$

Penelitian lain mengatakan faktor-faktor yang berhubungan dengan kualitas hidup lansia yaitu usia, tingkat pendidikan, penghasilan, pekerjaan, status pernikahan, disabilitas, penyakit, ADLs, dan dukungan sosial. Lansia yang masih memiliki pasangan dan memiliki dukungan sosial yang baik mengalami peningkatan kualitas hidup dibandingkan dengan mereka yang masih lajang, bercerai, atau berkabung karena hubungan sosial dengan pasangannya itu mempunyai efek protektif dan suportif. ${ }^{(14,16)}$ Lansia yang mempunyai tingkat pendidikan, penghasilan yang rendah, dan tidak bekerja mempunyai kemampuan memecahkan masalah dan strategi koping positif yang rendah. Lansia ini mempunyai situasi sosioekonomi yang rendah dan dapat membuat stres sehingga dapat menurunkan kualitas hidup mereka. ${ }^{(17)}$

Dari penilaian kualitas hidup, didapatkan aspek fisik lansia yang rendah, akan tetapi sebagian besar responden pada penelitian ini memiliki tingkat kemandirian yang mandiri. Faktor-faktor yang mempengaruhi tingkat kemandirian yaitu faktor kesehatan, dukungan sosial, dan dukungan keluarga. ${ }^{(18)}$ Jika dilihat dari usia, responden dalam penelitian ini sebagian besar termasuk golongan elderly (60-74 tahun). Hal ini disebabkan karena pada usia ini lansia masih mampu melakukan aktivitas sehari-hari yang bisa dilakukan sendiri, namun jika usia lansia semakin tua maka lansia akan memerlukan bantuan orang lain untuk memenuhi kebutuhan sehari-hari. ${ }^{(19)}$

Pada penelitian ini, setelah dilakukan uji statistik didapatkan tidak terdapat hubungan antara tingkat kebugaran dengan kualitas hidup lansia. Hasil ini sesuai dengan hasil penelitian yang menyatakan tidak terdapat hubungan antara kualitas hidup dengan kebugaran fisik. ${ }^{(13)}$ Beberapa peneliti lain setuju dengan hal ini, mengatakan kebugaran fisik belum tentu merupakan faktor penentu untuk persepsi diri tentang kualitas hidup lansia. ${ }^{(20-2)}$ Sebuah penelitian lain mengatakan meskipun seorang lansia memiliki gangguan fungsi tubuh yang tinggi, tetapi menunjukkan kepuasan yang lebih tinggi pada hidupnya. ${ }^{(20)}$

Hasil penelitian ini tidak sejalan dengan penelitian yang menyatakan terdapat hubungan antara kebiasaan olahraga dengan kualitas hidup lansia. Pada penelitian yang dilaksanakan di wilayah kerja puskesmas Wonokromo Surabaya tersebut, hampir semua responden dalam penelitiannya adalah anggota dari senam lansia sehingga lebih dari $60 \%$ dari responden memiliki kebugaran yang baik. Selain jumlah responden yang lebih besar, instrumen yang digunakan pada penelitian tersebut juga berbeda, yaitu untuk menilai kebugaran jasmani menggunakan kuesioner kebiasaan olahraga apakah lansia teratur atau tidak dalam berolahraga, jenis aktivitas, intensitas, durasi dalam berolahraga, sedangkan pada penelitian ini menggunakan non exercise fitness test. Hasil penelitian didapatkan kebiasaan olahraga berhubungan dengan kualitas hidup lansia penderita DM tipe 2, dan lansia penderita DM tipe 2 yang tidak teratur dalam olahraga mempunyai risiko 0.2 kali memiliki kualitas hidup yang buruk. ${ }^{(12)}$

Definisi dari kualitas hidup itu sendiri merupakan hal yang sangat sangat kompleks, multidimensi, dan subyektif yang mewakili pandangan seorang individu tentang apa yang di anggapnya sebagai unsur kehidupan yang sehat, atau berdasarkan pada pandangan mereka tentang dunia, masyarakat, dan individu. ${ }^{(23)}$ Oleh karena itu, setiap orang mempunyai definisi untuk bersantai, tentang kesehatan, kesejahteraan, kebiasaan dan gaya hidup yang bervariasi sesuai dengan sosial, 
ekonomi, konteks politik, dan budaya individu masing-masing. ${ }^{(20,22)}$ Menurut WHO, kualitas hidup dapat dinilai dari aspek fisik, psikologis, sosial, lingkungan. Kebugaran dapat digunakan untuk menilai energi seseorang apakah dia akan mudah lelah dalam melakukan suatu aktivitas, dimana hanya sebagian dari aspek fisik kualitas hidup lansia. ${ }^{(4)}$

\section{KESIMPULAN}

Berdasar hasil penelitian, dapat disimpulkan bahwa tidak terdapat hubungan yang bermakna antara tingkat kemandirian dan kebugaran dengan kualitas hidup lansia. Saran untuk penelitian selanjutnya adalah agar ditambahkan variabel-variabel lain yang dapat mempengaruhi baik kemandirian, kebugaran, maupun kualitas hidup pada lansia yang belum diteliti pada penelitian ini.

\section{UCAPAN TERIMA KASIH}

Dekan Fakultas Kedokteran Universitas Trisakti, Dr. dr. Raditya Wratsangka, Sp.OG(K).

Ketua RT dan RW 01 Jelambar Baru, Grogol, Jakarta Barat.

\section{REFERENSI}

1. Badan Pusat Statistik. Statistik Penduduk Lanjut Usia. 2017 [cited 2018 Jun 26]. Available from: https://bit.ly/2Zz4guT

2. Yuliati A, Baroya M, Ririanty M. Perbedaan kualitas hidup lansia yang tinggal di komunitas dengan di pelayanan sosial lanjut usia. E-Jurnal Pustaka Kesehatan. 2014;2(1):87-94.

3. Darmojo BD, Martono HH. Buku ajar BoedhiDarmojo:geriatri. Ed 5. Jakarta: Badan Penerbit FKUI; 2015. $108 \mathrm{p}$.

4. WHO. Programme on mental health WHOQOL user manual. Division of Mental Health and Prevention of Subtance Abuse. 2012 [cited 2018 Jun 26]. Available from: http://apps.who.int/iris/ bitstream/handle/10665/77932/WHO HIS HSI Rev.2012.03 eng.pdf? sequence $=1 \&$ is $\bar{A}$ llowed $=y$

5. Maryam R, Siti. Mengenal usia lanjut dan perawatannya. Jakarta: Salemba Medika; 2011. 55-6 $\mathrm{p}$.

6. Rohaedi S, Putri ST, Karimah AD. Tingkat kemandirian lansia dalam activity daily living di panti soisal tresna werdha Senja Rawi. Jurnal Pendidikan Keperawatan Indonesia. 2016;2(1):1621

7. Bernadeta, Ari E. Hubungan Kemandirian Dengan Kualitas Hidup Pada Lansia di Desa Margajaya RW 13 Kecamatan Ngamprah. Jurnal Ilmu Kesehatan. 2017;11(1)

8. Long S, Sudnongbua S. Quality of life among elderly people in Kampong Cham Province,
Cambodia. Southeast Asian J Trop Med Public Health. 2017;48(4):884-91

9. Nito PJB, Adenan, Herawati. Hubungan antara tingkat kemandirian dengan kualitas hidup lansia di panti sosial Tresna Werdha Budi Sejahtera propinsi Kalimantan Selatan. DK. 2013;1(2):52-8

10. Junaidi S. Pembinaan fisik lansia melalui aktivitas olahraga jalan kaki. Jurnal Media Ilmu Keolahragaan Indonesia. 2011;1:17-21

11. Sugiarto. Hubungan asupan energi, protein, dan konsumsi suplemen dengan tingkat kebugaran. Jurnal Media Ilmu Keolahragaan. 2012;2(2):94-5

12. Lara AG, Hidajah AC. Hubungan pendidikan, kebiasaan olahraga, dan pola makan dengan kualitas hidup lansia di puskesmas Wonokromo Surabaya. Jurnal Promkes. 2016;4(1):59-69

13. Maia TN, Alves Junior ED, Louro JQ, et al. Physical Fitness and quality of life of the elderly: a transversal study. 2014;13(4):559-67

14. Rohmah AIN, Purwaningsih, Bariyah K. Kualitas hidup lansia. Jurnal keperawatan. 2012;3(2):12032

15. Unsar S, Dindar I, Kurt S. Activities of daily living, quality of life, social support and depression levels of elderly individuals in Turkish society. J Pak Med Assoc. 2015;65:642-6

16. Laleh GE, Hamideh AR, Arash T. Factors Affecting Quality of Life among Elderly Population in Iran. Humanities and Social Sciences. 2017;5(1):26-30

17. Friedman EM, Love GD, Rosenkranz MA, et al. Socioeconomic status predicts objective and subjective sleep quality in aging women. Psychosom Med. 2007;69:682-91

18. Kodri, Rahmayati E. Faktor yang berhubungan dengan kemandirian lansia dalam melakukan aktivitas sehari-hari. Jurnal Keperawatan. 2016;12(1):81-9

19. Faqih A, Adina, Suratini. Hubungan tingkat kemandirian dengan kualitas hidup lansia di Padukuhan Karang Tengah Gamping Sleman Yogyakarta [skripsi]. [Yogyakarta]: Universitas 'Aisyiyah Yogyakarta; 2017. $13 \mathrm{p}$.

20. Enkvist A, Ekstron H, Elmstahl S. What factors affect life satisfaction (LS) among the oldest-old. Arch Gerontol Geriatr 2012;54(1):140-5

21. Hernadez R, Fernádez L, Alonso O. Satisfaction with life to functionality in active elderly people. Acts Esp Psiquiatr 2009;37(2):61-7

22. Menêses A L, Lima AHRA, Farah BQ, et al. Correlation Between Physical Fitness and Indicators of Quality of Life of Individuals with Intermittent Claudication. Rev Bras Med Esporte. 2011;17(3):175-8

23. Leal SMO, Borges EGS, Fonseca MA, et al. Efeitos do treinamento funcional na autonomia funcional, equilíbrio e qualidade de vida de idosas. R. bras. Ci. e Mov. 2009;17(3):61-9. 